\title{
QUEEN'S
UNIVERSITY
BELFAST
}

\section{Beyond carbon and energy: The challenge in setting guidelines for life cycle assessment of biofuel systems}

\author{
Czyrnek-Delêtre, M. M., Smyth, B. M., \& Murphy, J. D. (2017). Beyond carbon and energy: The challenge in \\ setting guidelines for life cycle assessment of biofuel systems. Renewable Energy, 105, 436-448. \\ https://doi.org/10.1016/j.renene.2016.11.043
}

\section{Published in: \\ Renewable Energy}

\section{Document Version:}

Peer reviewed version

Queen's University Belfast - Research Portal:

Link to publication record in Queen's University Belfast Research Portal

\section{Publisher rights}

(c) 2016 Elsevier Ltd. All rights reserved. This manuscript version is made available under the CC-BY-NC-ND 4.0 license

$\mathrm{http}: / /$ creativecommons.org/license, which permits distribution and reproduction for non-commercial purposes, provided the author and source are cited.

\section{General rights}

Copyright for the publications made accessible via the Queen's University Belfast Research Portal is retained by the author(s) and / or other copyright owners and it is a condition of accessing these publications that users recognise and abide by the legal requirements associated with these rights.

Take down policy

The Research Portal is Queen's institutional repository that provides access to Queen's research output. Every effort has been made to ensure that content in the Research Portal does not infringe any person's rights, or applicable UK laws. If you discover content in the Research Portal that you believe breaches copyright or violates any law, please contact openaccess@qub.ac.uk. 


\section{Accepted Manuscript}

Beyond carbon and energy the challenge in setting guidelines for life cycle assessment of biofuel systems

Magdalena Czyrnek-Delêtre, Beatrice M. Smyth, Jerry D. Murphy

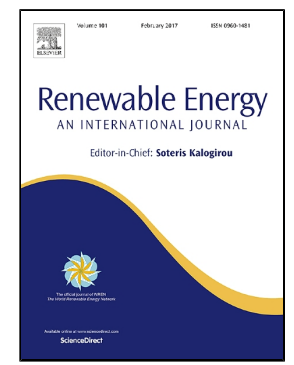

PII:

S0960-1481(16)31012-6

DOI:

10.1016/j.renene.2016.11.043

Reference:

RENE 8317

To appear in:

Renewable Energy

Received Date:

08 January 2016

Revised Date:

25 October 2016

Accepted Date:

17 November 2016

Please cite this article as: Magdalena Czyrnek-Delêtre, Beatrice M. Smyth, Jerry D. Murphy, Beyond carbon and energy the challenge in setting guidelines for life cycle assessment of biofuel systems, Renewable Energy (2016), doi: 10.1016/j.renene.2016.11.043

This is a PDF file of an unedited manuscript that has been accepted for publication. As a service to our customers we are providing this early version of the manuscript. The manuscript will undergo copyediting, typesetting, and review of the resulting proof before it is published in its final form. Please note that during the production process errors may be discovered which could affect the content, and all legal disclaimers that apply to the journal pertain. 


\section{Highlights:}

1. More than one functional unit should be used whenever possible

2. System boundaries should be expanded to include co- and by-products.

3. Climate, acidification, eutrophication, land use, and energy are the key indicators

4. Existing frameworks for biofuels LCA focus on greenhouse gases emissions 


\section{Beyond carbon and energy: the challenge in setting guidelines for life cycle assessment}

2 of biofuel systems

3 Magdalena Czyrnek-Delêtre ${ }^{1,2}$, Beatrice M. Smyth ${ }^{3}$, Jerry D. Murphy,1,2*

4 1. MaREI centre, Environmental Research Institute, University College Cork (UCC), Ireland,

52 School of Engineering, UCC, Ireland,

63 School of Mechanical and Aerospace Engineering, Queen's University, Belfast UK

7

8

9 Abstract:

10 Life cycle assessment (LCA) is a most suitable tool for a uniform assessment methodology of 11 sustainability of biofuel systems. However, there are no binding guidelines for LCA of biofuel 12 systems. Published LCAs use a range of methodologies, different system boundaries, impact 13 categories and functional units, various allocation approaches, and assumptions regarding by- and co14 products, as well as different reference systems to which the biofuel system is compared. The 15 European Renewable Energy Directive and the US Renewable Fuel Standard focus on greenhouse gas 16 (GHG) emissions. However, previous LCAs of biofuel systems have shown that a reduction of GHG emissions does not lead automatically to a decrease in other environmental impacts, and might in fact be associated with an increase in impacts such as acidification, eutrophication, and land use change.

19 In order to enable effective comparison of biofuel systems, the authors propose a framework for 20 biofuel LCA. System boundaries should be expanded to include the life cycle of by- and co-products.

21 Results should be reported using more than one functional unit. Burden shifting can be avoided by considering an array of impact categories including global warming potential and energy balance, along with eutrophication and acidification potential, and a land use indicator.

Keywords: life cycle assessment; sustainability guidelines; system boundaries, impact categories, biofuels. 


\section{Introduction}

\subsection{Background}

Total world energy consumption is predicted to increase by $56 \%$ between 2010 and 2040 [1]. The EU has set an overall mandatory target of $20 \%$ share of renewable energy in gross domestic consumption, and a target of $10 \%$ share of renewables in transport (RES-T), by 2020 [2].The US Energy Independence and Security Act of 2007 requires 18\% of transport fuel consumption to come from renewables by 2022 [3]. The use of biofuels, biogas or bioliquids as a sustainable and efficient energy source has been explored for decades [4,5]. For some time, especially in the context of peak oil, biofuels were considered a reliable renewable energy source, but their overall sustainability has been questioned in recent years [6], leading to increased focus on methods for its evaluation. Life cycle assessment (LCA) is one of the most promising approaches for evaluating the sustainability of biofuels [7] and for comparing biofuel systems. LCA is a multistage approach, which covers the full life cycle of a product. While LCA is an important tool for understanding biofuel systems, and supporting decision making, LCA procedures could be considerably strengthened in a number of key areas [8]. These include: i) methodology with goal and scope definition, ii) data collection based on real-life rather than lab scale facilities, and iii) multi-criteriality of LCA that considers all environmental impacts equally. These challenges are described in more detail below.

Goal and scope of the study, like functional unit, are often not clearly defined; sensitivity analyses are rarely performed [9]. Thomassen et al. stated that there is a lack of a generic framework for sustainability assessment of algal biofuels [10]. LCA studies of the same biofuel by different authors can give significantly different results, which can lead to the introduction of contradictory policies [11]. Such discrepancies are largely due to different methodological approaches and, although the need for a standardised methodology has been identified, there are as yet no guidelines for achieving this $[8,10-13]$. Moreover, many LCA studies do not specify the methodological choices made, which makes it almost impossible to replicate the study [14]. LCA addresses the life cycle of produced and consumed product [15], and is largely used by industry to assess a real-life product system. Advanced biofuels are not yet deployed on a large scale and industry data might not be available. Therefore, often LCA is based on laboratory data which makes the results much less accurate $[10,16]$.

A further weakness is that most existing LCA studies have focused only on energy and/or greenhouse gas (GHG) emissions. Reinhardt pointed out that majority of studies called LCA are in fact only GHG emissions and energy balances [9]. Lazarevic and Martin analysing LCA and sustainability studies in Sweden found that GHG emissions dominate other environmental impacts [17]. Ridley et al. assessed more than 1600 peer-reviewed papers on biofuels and found that the most discussed topics are production technologies, GHG emissions and agricultural production of substrates, whereas the impact of biofuels on biodiversity and human health was much less investigated [18]. This is in line with Raman et al. who argue that impact on human health and resources are understudied, when it 
comes to biofuel sustainability assessment [16]. Also, water, land use and land use change are seldom found in the literature [14]. GHG emissions and Global Warming Potential (GWP) are very important for LCA studies [2]. However, there are concerns that, although the use of biofuels may decrease GHG emissions, other detrimental environmental impacts, such as acidification, human toxicity, or land use change, may increase and should therefore also be taken into account in the LCA $[17,19,20]$. However, the inclusion of additional environmental impacts is hindered by the fact that some of the key parameters, such as indirect land use change or water use, are currently not well understood or lacking a transparent and mature calculation methodology $[11,13,17,19]$.

\subsection{Aims and Objectives}

Previous papers stressed a lack of guidelines for LCA of biofuels, and a need to propose a common framework $[8-10,12,13,19]$. With the overall goal of bridging this gap and assisting policy makers to make informed decisions based on solid scientific evidence, the aim of this paper is to investigate and make recommendations for improving the robustness and accuracy of biofuel LCA framework. The objectives of this paper are to:

- Discuss the existing frameworks providing guideline for LCA of biofuels

- Compare various approaches used in biofuel system LCA in terms of functional unit, system boundaries, reference scenario, allocation methodology and impact categories;

- Discuss how extensive the evaluations should be in order to produce sound results;

- Make recommendations for improving the robustness of the biofuel LCA framework.

\section{Methodology - construction of literature source database}

A literature search was conducted in Science Direct, Research Gate and Google Scholar, using both "biofuel" and "LCA" as keywords. This includes: life cycle assessment, analysis and approach. Initially, 54 papers were selected, these were published between 2006 and 2014 (Fig. 1). Out of this initial trawl, 16 papers were retained as these papers met the criteria under investigation in this paper. Papers were excluded based on repetitiveness (in terms of system boundaries and subject of studies), and scope and aim of the studies (e.g. studies focusing on infrastructure such as LCA of anaerobic digester; LCAs of biofuels different that biodiesel, bioethanol and biomethane; LCAs with an incomplete scope, missing one of the following: functional unit, scope, impact categories, allocation). Similarly, reviews, methodological papers and cost analyses were excluded. Thus the initial 54 papers were reduced to 16 papers for detailed investigation. These 16 papers were selected in such a way that three biofuel systems (biodiesel, bioethanol and biomethane) are represented, and also under a condition that each discussed at least four of the five headings in Table 1, namely: functional unit, system boundaries, reference system, allocation, and impact categories. Biogas was included as an energy vector that is very close to biomethane. A diverse range of substrates were selected from crops 
102

103

104

105

106

107

108

109

110

111

112

113

114

115

116

117

118

119

120

121

122

123

124

125

126

127

128

129

130

131

132

133

134

135

(rapeseed, palm oil, maize and grass), and from residues (tallow, used cooking oil, food waste, manures and straw). Third generation substrates were also selected (micro and macroalgae).

Additionally, to validate the focus of biofuel LCAs on GHG emissions a simple calculation was carried to evaluate the percentage of peer-reviewed LCAs according to impact categories assessed. These were classified into six groups: GHG or GWP, energy, both GHG and energy, other environmental impacts, land use and water. 39 papers were considered, which were published after 2008. These were screened for impact categories assessed (Fig. 5).

\section{LCA of biofuels- results}

\subsection{Existing LCA frameworks}

LCA norms ISO (International Standard Organization) 14040 and 14044 set a general framework for LCA of any goods or services [15,21]. Functional unit should reflect the function of the products; system boundaries and impact categories should stay consistent with the goal of the study; choices should be clearly stated and explained; in terms of allocation, ISO 14044 allows for any of the allocation methodologies, provided that the choice is explained and fits into the scope of study; however it is recommended to avoid allocation whenever possible by 1) dividing processes into subprocesses and collecting data related to sub-processes; or 2) by expanding the system (substitution) [15]. PAS (Publicly Available Specification for assessment of life cycle GHG of goods and services) follows ISO 14044 in terms of general guidelines, but concentrates only on GHG emissions [22]. The UNFCCC (United Nations Framework Convention on Climate Change) through its MethPanel discusses only the issue of allocation and agrees partially with ISO, postulating that all allocation procedures can be justified [3]. However, the International Energy Agency (IEA) in its BIOMITRE manual (BIOmass-based Climate Change MITigation through Renewable Energy) states that substitution may increase the complexity of the study, and therefore advocates in favour of allocation by market value or physical relationship, such as mass volume or calorific value [23]. BIOMITRE also gives more detailed recommendations suggesting that the FU should be mass or volume or energy content. It gives guidelines and examples for biofuels' system boundaries. The tool focusses only on carbon emissions as an indicator. This is in line with the EU European Renewable Energy Directive (RED), which limits the allocation possibilities to allocation by energy content (lower heating value) and sets a MJ of fuel as the FU [2]. RED is applied in the BioGrace Excel tool [24]. BioGrace is a harmonised tool that can be used in a European context for life cycle GHG calculation of biofuels. The system boundaries are pre-set but there is a possibility to create new entries. The calculation includes also direct land use change emissions. 


\subsection{Functional unit}

At the early stage of any LCA, the functional unit (FU) of product must be defined. The FU is a quantified description of the product system performance [15,25]. For biofuel, the product function might be the provision of fuel for transportation, or the processing of particular feedstock. Cherubini and Strømman [13] distinguished input- and output functional units. The FU can be expressed per mass of input substrate, such as one tonne of dry seaweed [26]. However, a majority of studies used an output-related FU, typically expressed in MJ of energy generated from a given feedstock [27,28], or in kilogram of produced fuel [29]. The EU RED recommends a FU of a MJ of fuel [2]. As the primary function of biofuel is to provide vehicle fuel, a commonly used FU is kilometres driven by a car or a truck transporting a given mass of freight [30,31]. For land-based biofuels, the most relevant FU was identified as land area under a crop [13].

The impact of FU was investigated by Lettens et al. [32]. Low-input energy crops were compared with traditional energy crops and it was found that if land surface was used as FU, conventional crops performed better in terms of GHG emissions, while if GJ of energy from crops was used as FU, then low-input crops performed better. Thamsiriroj and Murphy [33] [34] also explored the impact of choosing different FU, and came to contradictory conclusions when using GHG emissions per GJ or per ha as FU (Fig. 2). To better understand the findings of a LCA, Cherubini and Strømman [13] recommended using more than one FU. However LCA studies that present results using several FU are seldom found, and there is a lack of guidance on the appropriate selection of multiple FUs.

\subsection{System boundaries and reference system}

The boundaries of the system must be defined together with the goal and scope of the LCA. Processes and flows should be listed to consider which should be included in a LCA. Usually, there is more than one product delivered to the market from the same system. In such a case, the system boundaries might be expanded to include the life cycle of co-products, by-products, and residues [35]. Early LCAs of bioenergy systems did not include the life cycle of co- or by-products, thus giving a poor impression of biofuel systems environmental performance [31].

Some of the reviewed studies considered more than one system boundary [33,36-38]. However, only three take into account the use of biofuel in a vehicle, a boundary expansion, which can have a considerable impact on the results. Korres et al [39] found that when use of grass biomethane in a car is included (well to wheel), the GHG savings are 18\% lower than for well to tank analysis. Luo et al. [30] reported that expanding boundaries to include car driving as well as food and fodder production, led to lower GWP but higher impacts in other environmental categories (Table 1).

The reference system for a biofuel is typically a fossil fuel system delivering the same service, thus having the same function. The EU RED sets a reference value based on fossil fuels. This value 
represents the actual average GHG emissions from petrol and diesel within the EU that is set at $83.8 \mathrm{~g}$ $\mathrm{CO}_{2}$ eq / MJ for both fuels. Several of the reviewed studies follow the RED recommendations to calculate GHG reduction. Thamsiriroj and Murphy [34] used diesel as a reference system for biodiesel and Kaufman et al. [40] used gasoline for bioethanol.

The choice of reference system is not always straightforward. If biomethane displaces natural gas (as might be the case in a country with a high penetration of NGVs), then the savings in displacing natural gas (at $50.3 \mathrm{~g} \mathrm{CO}_{2}$ eq / MJ natural gas) [41] appear significantly less than if displacing petrol or diesel (at $83.8 \mathrm{~g} \mathrm{CO}_{2}$ eq / MJ), as might be the case in a country with a low penetration of NGVs. Generally, the reduction in GHG emissions will be higher if biofuel systems are compared with carbon intensive fuels, such as coal, and lower if compared with 'cleaner fuels', such as natural gas. In the majority of studies, the boundaries of the reference system did not extend beyond the production and use of fossil fuel $[33,34,39,40,42]$. However, Börjesson and Berglund $[43,44]$ defined boundaries that included also the production of mineral fertilizers and alternative uses of the raw materials or land. By expanding the system's boundaries, Börjesson and Berglund $[43,44]$ detected potential indirect benefits derived from biogas systems linked to changes in handling of feedstocks and digestate.

\subsection{Allocation methodology}

If process chains deliver more than one product, all system flows must be divided between different products delivered by the system. This division procedure is called allocation whereby all flows are weighted and divided between the products of the system in proportion to the products' energy content, mass or market value (Fig. 3). Another approach is subdivision, in which multifunctional processes are sub-divided into sub-processes, and separate data are collected for each mono-functional process [45]. No-allocation approach is the most conservative; all burdens are assigned to the main product.

The third major approach is system expansion, in which the boundaries of the system are expanded to include the functions and life cycles of co-products. System expansion and substitution are often used as synonyms. However, while the former approach is only about expanding boundaries, the latter considers all products and/or functions that can be replaced by the co-products and by-products of the system under analysis. For example, digestate as a co-product of a biogas system can be used as fertilizer and therefore the system gets credits for reducing the use of mineral fertilizers [46].

Despite the fact that choosing an allocation methodology is a fundamental step in LCA, different organisations recommend different approaches (Table 2) and several studies found that different allocation approaches can lead to completely different results $[33,40,42]$. 
208

209

210

211

212

213

214

215

216

217

218

219

220

221

222

223

224

225

226

227

228

229

230

231

232

233

234

235

236

237

238

239

240

241

242

\subsubsection{Comparing biodiesel and grass biomethane}

Thamsiriroj and Murphy [33] used three different allocation approaches to analyse rapeseed biodiesel, tallow biodiesel, UCO (used cooking oil) biodiesel, and grass biomethane. They found the biggest difference when assessing tallow biodiesel, with GHG savings varying between 33\% (no allocation) and $150 \%$ (substitution approach). In the case of grass biomethane, GHG savings increased from $54 \%$ (no allocation) to $129 \%$ (system expansion). The simplest system, UCO biodiesel, seemed the least affected by the choice of the allocation method.

\subsubsection{LCA comparison of rapeseed biodiesel system using various allocation approaches}

Stephenson et al. [47] considered that an allocation based on direct substitution was the most appropriate for rapeseed biodiesel system (scenario 2; Fig. 4). However, if the product being replaced is a by-product of another process, direct substitution becomes difficult to implement, and therefore Stephenson et al. applied allocation based on market prices (scenarios 1a and 1b; Fig. 4).

Thamsiriroj and Murphy [48] tested various scenarios, including no-allocation (scenario 0; Fig. 4), and substitution of various co-products (scenarios 3-6; Fig. 4). Compared to economic allocation (1a and 1b; Fig. 5), the direct substitution (scenario 2; Fig. 4) resulted in higher GHG savings and lower total energy consumption. If electricity and heat generated from rapeseed meal in CHP were used to substitute grid electricity and heat from coal or gas, the GWP decreased by $92 \%$ and total energy requirements by $216 \%$. With the no-allocation method, however, the reduction in GHG emissions was only $28 \%$. The highest GHG savings (135\%) resulted from the use of rape cake for animal feed, glycerol for heat production, and straw for thermal energy (scenario 4; Fig. 4). Using rape cake as animal feed saved GHG emissions from the production and transport of soybean meal, usually imported to Ireland from South America. Stephenson et al. [47] did not consider the burden of fodder production when rape meal is used to generate energy.

\subsubsection{Assessing corn stover-based ethanol using system expansion, and allocation by mass, energy and economic value}

In a case study of corn stover ethanol, Luo et al. [30] showed that using an economic allocation gave much higher results for GWP of bioethanol in comparison to mass/ energy allocation approaches. This is because the corn/ stover allocation ratio shifted from 1.7 to 7.5 when switching from mass/ energy allocation to economic allocation.

\subsubsection{Assessing bioethanol using six allocation methodologies}

Kraatz et al. [42] analyzed ethanol production from corn, with dried distillers grains and solubles (DDGS) as co-product. Using no-allocation approach and system expansion resulted in the highest energy intensity and highest GWP (see section 3.5). Conversely, mass, energy and economic allocation gave the lowest values for energy intensity and GWP of bioethanol produced. 


\subsection{Impact categories}

Life cycle impact assessment (LCIA) methodologies model the pathway of substances and link them to effects. There is a large array of LCIA methodologies that propose diverse indicators or/and calculate the same indicator using different models. The International Reference Life Cycle Data System (ILCD) handbook reviews a wide range of methods for impact assessment, and provides LCA practitioners with recommendation on indicators and models used in LCIA [49,50]. The handbook was developed for LCAs in European context by the European Commission Joint Research Centre. EDIP 2003, ReCiPe or CML 2001 quoted in this study, are widely used methods [51]. The midpoint approach translates environmental impacts into mechanisms such as acidification, eutrophication, or climate change, while endpoint methodologies concentrate on damages and express impacts on the three following: human health, ecosystems and natural resources [52,53].

\subsubsection{LCA based on energy and carbon balances}

The majority of biofuel LCAs in the literature look only at GHG emissions or GWP, and/or energy balance [13]. From 39 papers sampled in Science Direct that used LCA in the title, about half examined both carbon and energy, while only $26 \%$ considered also other environmental impacts (Fig. 5). Stephenson et al. [47] reported on GWP and primary energy requirement (EDIP 2003) [54]. Thamsiriroj and Murphy [34] calculated GHG emissions and reduction according to EU RED recommendations, as well as the gross and net energy of both rapeseed and palm oil biodiesel. A similar approach was employed by Smyth et al. [55] and Korres et al. [39] assessing the sustainability of grass biomethane. In a paper by Kraatz et al., corn grain ethanol was assessed using energy intensity and GHG (Fig. 6) [42]. When looking at energy intensity, electricity consumption, drying of DDGS and corn farming show the highest contribution to the overall impact. This changed when looking at GHG, where $70 \%$ of impact comes from electricity alone.

\subsubsection{LCA based on impact factors beyond carbon and energy}

Measuring of sustainability in terms of impacts beyond carbon and/or energy often gave different results to when just carbon and/or energy were assessed. Aguirre-Villegas et al. [56] used four sustainability indicators: GWP; ammonia emissions; depletion of fossil fuel (DFF); and nutrient form and fate. They found that the anaerobic digestion (AD) pathway in comparison to other manure utilisations had the lowest values for GWP and DFF, but had the highest $\mathrm{NH}_{3}$ emissions. Tufvesson et al. [36] in assessing biogas from industrial residues looked at GHG emissions, eutrophication, acidification, and energy balance. While GHG emissions were reduced whatever the substrate, impacts of both eutrophication and acidification were higher for biogas than fossil fuel systems. Only 
Poeschl et al. [37,38] included land use change indicators (land transformation and occupation) as a part of the ReCiPe method [51].

\section{Discussion: overcoming the challenges}

\subsection{Existing LCA frameworks}

From the frameworks listed in Table 2, BIOMITRE and RED are the only one specifically developed for biofuels and biomass. RED also provides the most detailed recommendations on LCA of biofuels. BioGrace is currently the only integrated tool that complies with RED and can be used by farmers, policy makers and consultants within Europe [57]. It is an intuitive tool with simple interface that allows even an unexperienced LCA analyst to get a quick GHG calculation [24]. The tool provides also a liberty to change parameters and introduce more specific data. However, BioGrace can be applied only for GHG calculations. Moreover, the RED does not give any recommendation on extending the impact assessment beyond carbon. Also, despite the harmonisation, the RED still permits methodological choices that can lead to different results for same biofuel pathway. [58]

\subsection{Functional unit}

The choice of FUs should reflect biofuel life cycle stages (Fig. 7). Thus, if feedstock requires agricultural land, then LCA results should be reported on a per ha basis, and if biofuel is produced for transportation, then results should be reported on a per km basis. LCA results as per each life cycle stage should be available using different FU.

\subsection{System boundaries and reference system}

The definition of the system's boundaries and choice of the reference system are crucial, as the results of LCA vary according to the reference system chosen. In order to present a comprehensive understanding of the system, boundaries should be expanded to include co-products, by-products and residues (Fig. 7). The boundaries of the reference system should be the same as those of the primary system under analysis, and the choice of reference system should be informed by the goal of the analysis. It may be appropriate to define a reference system for each stage of the life cycle process, such as alternative land use and LCA of products that are being replaced by co- and by-products. However, the authors recognise that expanding the reference system boundaries and using multiple reference systems can considerably increase analysis complexity, and therefore recommend that the primary focus is on defining a reference system according to the analysis goal.

\subsection{Allocation methodology}

From the assessed studies, LCA results depend heavily on type of allocation chosen. Van der Voet et al. stressed that substitution implies higher variability in the results [14]. However, the authors believe 
313

314

315

316

317

318

319

320

321

322

323

324

325

326

327

328

329

330

331

332

333

334

335

336

337

338

339

340

341

342

343

344

345

346

347

348

349

that co- and by-products should be included in biofuel LCA. Complex processes should be subdivided and data collected for each sub-process by linking of inputs and outputs to products, and coand by-products. If this is not possible due to lack of specific data and/or multiplicity of co-/ byproducts, then substitution should be applied (Fig. 7).

\subsection{Impact categories}

Since the majority of LCAs look only at GHG and energy balance, this can lead to the problem of burden shifting; where a biofuel system might achieve a high level of GHG reduction but could also impact the environment in other ways, for example through acidification and eutrophication [30]. In line with previous studies $[14,17,36-38,56]$, the authors recommend broadening LCAs to include impacts other than just carbon and energy. The ISO does not set a list of recommended impact categories for life cycle impact assessment, but highlights the importance of choosing these in line with the goal and scope of the study [15].

A comprehensive LCA study would investigate a range of environmental impacts such as climate change, impact on human health, ecotoxicity, acidification and eutrophication of environment, ozone layer depletion. While assessment of all these factors would certainly be desirable to gain a full understanding of the system, it may not be practical due to time and resource constraints. A further difficulty is the current lack of knowledge of some parameters and/or their poor integration in LCA studies, particularly indirect effects such as land use change and nitrogen emissions [20,59].

The authors limited the number of recommended indicators to the five listed in Table 3. The ILCD handbook was employed to assess the existing indicators for climate change, acidification, eutrophication and land use. Only the midpoint categories were considered. Both mid- and endpoint approaches have their advantages and disadvantages, but midpoint categories are much more accurate and precise, and bring less uncertainty to the model, unlike the endpoint approach that requires weighting of the categories [52].

To assess climate change, all LCIA methodologies use the GWP midpoint indicator developed by the Intergovernmental Panel on Climate Change (IPCC) [50]. The GWP should be always based on the latest IPCC report, in this case the Fifth Assessment Report [60]. GWP can be calculated over a 20, 50 and 100-year timeframe. Well-mixed GHGs, such as $\mathrm{CO}_{2}, \mathrm{CH}_{4}$, and $\mathrm{N}_{2} \mathrm{O}$ (including direct and indirect emissions from $\mathrm{NH}_{3}$ and $\mathrm{NO}$ ) are included. The GWP unit is $\mathrm{kg} \mathrm{CO}_{2}$ eq.

Acidification is mainly caused by the airborne acidifying substances, such as ammonia $\left(\mathrm{NH}_{3}\right)$ (after nitrification in the soil when nitrite is produced), nitrogen oxides $\left(\mathrm{NO}_{\mathrm{x}}\right)$ and sulphur dioxide $\left(\mathrm{SO}_{2}\right)$ (largely from fossil fuels combustion) [61]. The ILCD evaluated the accumulated exceedance (AE) model as the most suitable $[52,53,62]$. This method is widely accepted and used by the European Commission and the United Nation Economic Commission for Europe for policy purposes. It uses critical load of nutrients to quantify the sensitivity of the ecosystem. It also provides characterization factors that are country specific. It is expressed in moles of hydrogen ion $\left(\mathrm{H}^{+}\right)$eq. 
350

351

352

353

354

355

356

357

358

359

360

361

362

363

364

365

366

367

368

369

370

371

372

373

374

375

376

377

378

379

380

381

382

383

384

385

386

Eutrophication potential examines the impacts of the surplus of nitrogen and phosphorus on the terrestrial and aquatic ecosystems (marine and freshwater). Terrestrial eutrophication is caused by deposition of airborne $\mathrm{N}$ emissions, such as $\mathrm{NO}_{\mathrm{x}}$ (combustion processes), and $\mathrm{NH}_{3}$ (agriculture). For terrestrial eutrophication, ILCD recommends the AE model $[52,53,62]$. The indicator is expressed in $\mathrm{kg} \mathrm{N}$ eq [52]. Freshwater and marine eutrophication is induced by waterborne emissions, such as nitrate, phosphate and other $\mathrm{N}$ and $\mathrm{P}$ compounds [52]. It is recommended to use the ReCiPe method, as it models best the aquatic fate of emissions; however it is restricted only to European countries. The indicator is expressed in $\mathrm{kg} \mathrm{P}$ eq.

Land use indicators reflect the changes to ecosystems due to the effects of land occupation and transformation. To assess the impact of land use the ILCD handbook recommended the method by Milà i Canals et al., based on soil organic matter (SOM) [63,64]; however the level of recommendation is a grade lower than for the other impact categories discussed above [50]. The drawback of this method is that the LCA practitioner must calculate the case-specific characterisation factors based on collected data, such as SOM value before and after the land occupation and SOM value of the reference system. Moreover, the method presents a limited impact indicator based on SOM that considers soil quality but does not include the impact on soil biodiversity [52]. Alternatively, the midpoint ReCiPe method can be applied, but it accounts only for surface area of transformed and occupied land (expressed in $\mathrm{m}^{2}$ ).

An energy indicator is typically associated with the assessment of energy vectors such as biofuels. It requires thorough data collection on energy inputs and outputs. It can take various forms, such as: 1) energy balance (energy output to input ratio), 2) net energy (gross energy of the product minus parasitic energy demand of the processes), 3) land use energy efficiency (for land-based biofuels; energy produced per unit area).

Traditionally, LCA is a tool for assessment of global impacts [65]. This is still valid for climate change, but for impacts such as acidification and eutrophication that occur locally, there is a need for country- or site-specific characterisation factors. ReCiPe and CML methods include the European average factor [17,50], while Seppala et al [53] and Posch et al [62] went even further to include EU country-specific factors for acidification and terrestrial eutrophication. Finnveden and Nilsson argue that the site-specific factors are needed to allow including the local conditions into the model [17].

To conclude, there is a need for a framework on impact categories for biofuels assessment. These should include at least the categories described above: climate change, acidification, eutrophication, land use, and energy. Further research should provide LCA practitioners with site-specific factors for acidification, eutrophication and land use.

\section{Concluding remarks}

A sound evaluation of biofuel systems requires conducting a full cradle to grave LCA. Valid LCA studies should consider other sustainability indicators in addition to GHG emissions and energy 
balances. Standard requirements should include functional unit, system boundaries, allocation methodology, and environmental indicators. This unified methodology will allow comparing biofuel LCA studies, which currently is not possible as different studies follow different rules. Whereas it is preferable that full LCA is carried out in academia, industry should have access to a simplified and cost-effective version of LCA. LCA is a powerful tool but needs to continue to be refined as knowledge of the science grows. The recommendations outlined in this paper should go some way towards achieving this.

\section{References}

[1] U.S. Energy Information Agency, International Energy Outlook 2013, Outlook 2013. (2013) 312. doi:EIA-0484(2013).

[2] European Parliament and Council, Directive 2009/28/EC of the European Parliament and of the Council of 23 April 2009 on the promotion of the use of energy from renewable sources and amending and subsequently repealing Directives 2001/77/EC and 2003/30/EC, Official Journal of the European Union, OJ L 140, 5.6.2009, pp. 16-47, 2009.

[3] B.D. Yacobucci, K.S. Bracmort, Calculation of Lifecycle Greenhouse Gas Emissions for the Renewable Fuel Standard, (2009) 1-12.

[4] W.E. Tyner, The US Ethanol and Biofuels Boom: Its Origins, Current Status, and Future Prospects, Bioscience. 58 (2008) 646. doi:10.1641/B580718.

[5] D. Songstad, P. Lakshmanan, J. Chen, W. Gibbons, S. Hughes, R. Nelson, Historical perspective of biofuels: Learning from the past to rediscover the future, Biofuels Glob. Impact Renew. Energy, Prod. Agric. Technol. Adv. 45 (2011) 1-7. doi:10.1007/978-1-4419-7145$6 \_1$.

[6] R. Rathmann, A. Szklo, R. Schaeffer, Land use competition for production of food and liquid biofuels: An analysis of the arguments in the current debate, Renew. Energy. 35 (2010) 14-22. doi:10.1016/j.renene.2009.02.025.

[7] A. Jensen, L. Hoffman, B. Moller, S. Anders, et al., Life Cycle Assessment: A guide to approaches, experiences and information sources, 1997.

[8] M. Brandão, G. Heath, J. Cooper, What Can Meta-Analyses Tell Us About the Reliability of Life Cycle Assessment for Decision Support?, J. Ind. Ecol. 16 (2012) 3-7. doi:10.1111/j.15309290.2012.00477.x.

[9] G. Reinhardt, Overview, status and prospects on LCA for algae products, in: Keynote Speech. 3rd Eur. Work. Life Cycle Anal. Algal Based Biofuels Biomater., Brussels, 2015.

[10] G. Thomassen, M. Van Dael, B. Lemmens, S. Van Passel, A sustainability assessment framework for algal-based biorefineries, in: Ban, Marko, et al. (Eds.), Digit. Proc. 10th Conf. Sustain. Dev. Energy, Water Environ. Syst. - SDEWES2015, Zagreb: University of Zagreb, 
Faculty of Mechanical Engineering and Naval Architecture, 2015: pp. 1-21.

[11] A. Benoist, D. Dron, A. Zoughaib, Origins of the debate on the life-cycle greenhouse gas emissions and energy consumption of first-generation biofuels - A sensitivity analysis approach, Biomass and Bioenergy. 40 (2012) 133-142. doi:10.1016/j.biombioe.2012.02.011.

[12] E. Gnansounou, A. Dauriat, J. Villegas, L. Panichelli, Life cycle assessment of biofuels: Energy and greenhouse gas balances, Bioresour. Technol. 100 (2009) 4919-4930. doi:10.1016/j.biortech.2009.05.067.

[13] F. Cherubini, A.H. Strømman, Life cycle assessment of bioenergy systems: State of the art and future challenges, Bioresour. Technol. 102 (2011) 437-451. doi:10.1016/j.biortech.2010.08.010.

[14] E. van der Voet, R.J. Lifset, L. Luo, Life-cycle assessment of biofuels, convergence and divergence, Biofuels. 1 (2010) 435-449. doi:10.4155/bfs.10.19

[15] International Standard Organization (ISO), ISO 14044:2006 Environmental management - Life cycle assessment - Requirements and guidelines, Geneva : International Organization for Standardization, 2006. http://www.iso.org/iso/catalogue_detail? csnumber=38498.

[16] M.K. Raman Sujatha, Mohr Alison, Helliwell Richard, Ribeiro Barbara, Shortall Orla, Smith Robert, Intergrating social and value dimensions into sustainability assessment of lignocellulosic biofuels, Biomass and Bioenergy. (2015) 1-14. doi:10.1016/j.biombioe.2015.04.022.

[17] D. Lazarevic, M. Martin, Life cycle assessments, carbon footprints and carbon visions: Analysing environmental systems analyses of transportation biofuels in Sweden, J. Clean. Prod. 137 (2016) 249-257. doi:10.1016/j.jclepro.2016.07.075.

[18] C.E. Ridley, C.M. Clark, S.D. Leduc, B.G. Bierwagen, B.B. Lin, A. Mehl, et al., Biofuels: network analysis of the literature reveals key environmental and economic unknowns., Environ. Sci. Technol. 46 (2012) 1309-15. doi:10.1021/es2023253.

[19] F. Cherubini, GHG balances of bioenergy systems - Overview of key steps in the production chain and methodological concerns, Renew. Energy. 35 (2010) 1565-1573. doi:10.1016/j.renene.2009.11.035.

[20] S.C. Davis, K.J. Anderson-Teixeira, E.H. DeLucia, Life-cycle analysis and the ecology of biofuels, Trends Plant Sci. 14 (2009) 140-146. doi:10.1016/j.tplants.2008.12.006.

[21] International Standard Organization (ISO), ISO 14040:2006 Environmental management -Life cycle assessment -- Principles and framework, 2006. http://www.iso.org/iso/catalogue_detail?csnumber=37456.

[22] Defra, DECC, BIS, PAS 2050: 2011 Specification for the assessment of the life cycle greenhouse gas emissions of goods and services, 2011. doi:978 0580713828.

[23] R. Horne, M. R, BIOMITRE Technical Manual, 2004. http://www.globalbioenergy.org/bioenergyinfo/bioenergy-and-climate- 
change/detail/en/c/19282/.

[24] BioGrace, User manual for the BioGrace Excel tool. Version 4d, (2015). www.biograce.net/home.

[25] G. Rebitzer, T. Ekvall, R. Frischknecht, D. Hunkeler, G. Norris, T. Rydberg, et al., Life cycle assessment Part 1: Framework, goal and scope definition, inventory analysis, and applications, Environ. Int. 30 (2004) 701-720. doi:10.1016/j.envint.2003.11.005.

[26] M. Alvarado-Morales, A. Boldrin, D.B. Karakashev, S.L. Holdt, I. Angelidaki, T. Astrup, Life cycle assessment of biofuel production from brown seaweed in Nordic conditions, Bioresour. Technol. 129 (2013) 92-99. doi:10.1016/j.biortech.2012.11.029.

[27] D. Luo, Z. Hu, D.G. Choi, V.M. Thomas, M.J. Realff, R.R. Chance, Life cycle energy and greenhouse gas emissions for an ethanol production process based on blue-green algae., Environ. Sci. Technol. 44 (2010) 8670-8677. doi:10.1021/es1007577.

[28] X. Wang, E. Nordlander, E. Thorin, J. Yan, Microalgal biomethane production integrated with an existing biogas plant: A case study in Sweden, Appl. Energy. 112 (2013) 478-484. doi:10.1016/j.apenergy.2013.04.087.

[29] J. Yang, M. Xu, X. Zhang, Q. Hu, M. Sommerfeld, Y. Chen, Life-cycle analysis on biodiesel production from microalgae: Water footprint and nutrients balance, Bioresour. Technol. 102 (2011) 159-165. doi:10.1016/j.biortech.2010.07.017.

[30] L. Luo, E. Van Der Voet, G. Huppes, H. a. Udo De Haes, Allocation issues in LCA methodology: A case study of corn stover-based fuel ethanol, Int. J. Life Cycle Assess. 14 (2009) 529-539. doi:10.1007/s11367-009-0112-6.

[31] G. Zaimes, M. Borkowski, V. Khanna, Life-Cycle Environmental Impacts of Biofuels and Coproducts, in: V. Gupta, M. Tuohy (Eds.), Biofuel Technol. Recent Dev., Springer-Verlag Berlin Heidelberg, 2013: p. 471=99.

[32] S. Lettens, B. Muys, R. Ceulemans, E. Moons, J. Garcia, P. Coppin, Energy budget and greenhouse gas balance evaluation of sustainable coppice systems for electricity production, Biomass and Bioenergy. 24 (2003) 179-197. doi:10.1016/S0961-9534(02)00104-6.

[33] T. Thamsiriroj, J.D. Murphy, A critical review of the applicability of biodiesel and grass biomethane as biofuels to satisfy both biofuel targets and sustainability criteria, Appl. Energy. 88 (2011) 1008-1019. doi:10.1016/j.apenergy.2010.10.026.

[34] T. Thamsiriroj, J.D. Murphy, Is it better to import palm oil from Thailand to produce biodiesel in Ireland than to produce biodiesel from indigenous Irish rape seed?, Appl. Energy. 86 (2009) 595-604. doi:10.1016/j.apenergy.2008.07.010.

[35] G. Sarantakos, C. Opal, Roundtable on Sustainable Biofuels Substitution versus allocation definitions, 2006 (2008) 1-5.

[36] L.M. Tufvesson, M. Lantz, P. Börjesson, Environmental performance of biogas produced from industrial residues including competition with animal feed - Life-cycle calculations according 
to different methodologies and standards, J. Clean. Prod. 53 (2013) 214-223. doi:10.1016/j.jclepro.2013.04.005.

[37] M. Poeschl, S. Ward, P. Owende, Environmental impacts of biogas deployment - Part I: Life Cycle Inventory for evaluation of production process emissions to air, J. Clean. Prod. 24 (2012) 168-183. doi:10.1016/j.jclepro.2011.10.039.

[38] M. Poeschl, S. Ward, P. Owende, Environmental impacts of biogas deployment - Part II: Life Cycle Assessment of multiple production and utilization pathways, J. Clean. Prod. 24 (2012) 184-201. doi:10.1016/j.jclepro.2011.10.030.

[39] N.E. Korres, A. Singh, A.-S. Nizami, J.D. Murphy, Is grass biomethane a sustainable transport biofuel?, Biofuels, Bioprod. Biorefining. 4 (2010) 310-325. doi:10.1002/bbb.

[40] A.S. Kaufman, P.J. Meier, J.C. Sinistore, D.J. Reinemann, Applying life-cycle assessment to low carbon fuel standards-how allocation choices influence carbon intensity for renewable transportation fuels, Energy Policy. 38 (2010) 5229-5241. doi:10.1016/j.enpol.2010.05.008.

[41] Energy Information Administration, Independent Statistics \& Analysis. CO2 emissions, (2013). http://www.eia.gov/environment/emissions/co2_vol_mass.cfm (accessed September 5, 2014).

[42] S. Kraatz, J.C. Sinistore, D.J. Reinemann, Energy intensity and global warming potential of corn grain ethanol production in Wisconsin (USA), Food Energy Secur. 2 (2013) 207-219. doi:10.1002/fes3.27.

[43] P. Börjesson, M. Berglund, Environmental systems analysis of biogas systems-Part I: Fuelcycle emissions, Biomass and Bioenergy. 30 (2006) 469-485. doi:10.1016/j.biombioe.2005.11.014.

[44] P. Börjesson, M. Berglund, Environmental systems analysis of biogas systems-Part II: The environmental impact of replacing various reference systems, Biomass and Bioenergy. 31 (2007) 326-344. doi:10.1016/j.biombioe.2007.01.004.

[45] S. Kraatz, D.J. Reinemann, W.E. Berg, Energy inputs for corn production in Wisconsin (U.S.) and Germany, Appl. Eng. Agric. 25 (2009) 653-662.

[46] M. Brander, Substitution : a Problem with Current Life Cycle Assessment Standards, (2012) 3.

[47] A.L. Stephenson, J.S. Dennis, S.A. Scott, Improving the sustainability of the production of biodiesel from oilseed rape in the UK, Process Saf. Environ. Prot. 86 (2008) 427-440. doi:10.1016/j.psep.2008.06.005.

[48] T. Thamsiriroj, J.D. Murphy, Can rape seed biodiesel meet the European union sustainability criteria for biofuels?, Energy and Fuels. 24 (2010) 1720-1730. doi:10.1021/ef901432g.

[49] European Commission -- Joint Research Centre -- Institute for Environment and Sustainability, International Reference Life Cycle Data System (ILCD) Handbook -- General guide for Life Cycle Assessment -- Detailed guidance, 2010. doi:10.2788/38479.

[50] JRC European commission, ILCD Handbook: Recommendations for Life Cycle Impact 
Assessment in the European context, 2011. doi:10.278/33030.

[51] M. Goedkoop, R. Heijungs, A. De Schryver, J. Struijs, R. van Zelm, ReCiPe 2008. A LCIA method which comprises harmonised category indicators at the midpoint and the endpoint level. Report 1. Characterisation., 2013. doi:http://www.lcia-recipe.net.

[52] European Commission - Joint Research Centre - Institute for Environment and Sustainability, International Reference Life Cycle Data System (ILCD) Handbook: Framework and Requirements for Life Cycle Impact Assessment Models and Indicators, 2010. doi: $10.2788 / 38719$.

[53] J. Seppälä, M. Posch, M. Johansson, J.-P. Hettelingh, Country-dependent Characterisation Factors for Acidification and Terrestrial Eutrophication Based on Accumulated Exceedance as an Impact Category Indicator (14 pp), Int. J. Life Cycle Assess. 11 (2006) 403-416. doi:10.1065/lca2005.06.215.

[54] L.C. Dreyer, A.L. Niemann, M.Z. Hauschild, Comparison of Three Different LCIA Methods: EDIP97, CML2001 and Eco-indicator 99, Int. J. Life Cycle Assess. 8 (2003) 191-200. doi:10.1007/BF02978471.

[55] B.M. Smyth, J.D. Murphy, C.M. O'Brien, What is the energy balance of grass biomethane in Ireland and other temperate northern European climates?, Renew. Sustain. Energy Rev. 13 (2009) 2349-2360. doi:10.1016/j.rser.2009.04.003.

[56] H. Aguirre-Villegas, R. Larson, D.J. Reinemann, From waste-to-worth: energy, emissions, and nutrient implications of manure processing pathways, Biofuels, Bioprod. Biorefining. (2014). doi:10.1002/bbb.

[57] C. Peter, K. Helming, C. Nendel, Do greenhouse gas emission calculations from energy crop cultivation re fl ect actual agricultural management practices? - A review of carbon footprint calculators, Renew. Sustain. Energy Rev. 67 (2016) 461-476. doi:10.1016/j.rser.2016.09.059.

[58] A.M. Hennecke, M. Faist, J. Reinhardt, V. Junquera, J. Neeft, H. Fehrenbach, Biofuel greenhouse gas calculations under the European Renewable Energy Directive - A comparison of the BioGrace tool vs. the tool of the Roundtable on Sustainable Biofuels, Appl. Energy. 102 (2013) 55-62. doi:10.1016/j.apenergy.2012.04.020.

[59] F. Cherubini, N.D. Bird, A. Cowie, G. Jungmeier, B. Schlamadinger, S. Woess-Gallasch, Energy- and greenhouse gas-based LCA of biofuel and bioenergy systems: Key issues, ranges and recommendations, Resour. Conserv. Recycl. 53 (2009) 434-447. doi:10.1016/j.resconrec.2009.03.013.

[60] G. Myhre, D. Shindell, F.-M. Breon, W. Collins, J. Fuglestvedt, J. Huang, et al., Anthropogenic and natural radiative forcing, in: T.F. Stocker, D. Qin, G.-K. Plattner, M.M. Tignor, S. Allen, J. Boschung, et al. (Eds.), Clim. Chang. 2013 Phys. Sci. Basis Contrib. Work. Gr. I to Fifth Assess. Rep. Intergov. Panel Clim. Chang., Cambridge, United Kingdom and New York, NY, USA: Cambridge University Press, 2013: p. 731. 
[61] European Commission - Joint Research Centre - Institute for Environment and Sustainability, Characterisation factors of the ILCD Recommended Life Cycle Impact Assessment methods: database and supporting information, 2012. doi:10.2788/60825.

[62] M. Posch, J. Seppälä, J.P. Hettelingh, M. Johansson, M. Margni, O. Jolliet, The role of atmospheric dispersion models and ecosystem sensitivity in the determination of characterisation factors for acidifying and eutrophying emissions in LCIA, Int. J. Life Cycle Assess. 13 (2008) 477-486. doi:10.1007/s11367-008-0025-9.

[63] L. Milà i Canals, C. Bauer, J. Depestele, A. Dubreuil, R.F. Knuchel, Key Elements in a Framework for Land Use Impact Assessment Within LCA Land Use in LCA, Int. J. Life Cycle Assess. 12 (2007) 5-15.

[64] L. Milà i Canals, J. Romanyà, S.J. Cowell, Method for assessing impacts on life support functions (LSF) related to the use of "fertile land" in Life Cycle Assessment (LCA), J. Clean. Prod. 15 (2007) 1426-1440. doi:10.1016/j.jclepro.2006.05.005.

[65] G. Finnveden, M. Nilsson, Site-dependent life-cycle impact assessment in Sweden, Int. J. Life Cycle Assess. 10 (2005) 235-239. doi:DOI 10.1065/lca2005.05.209.

[66] UNFCCC Methodologies (Meth) Panel, Guidelines on apportioning emissions from production processes between main product and co- and by-products, Methodologies Panel Meeting 045, 2004. https://cdm.unfccc.int/Panels/meth/meeting/08/035/mp_035_an11.pdf. 
592

593

594

595

596

597

598

599

600

601

602

603

604

605

606

607

608

609

610

611

612

613

614

615

616

617 Fig. 7. Flowchart with recommendations for biofuels LCA. fuel, palm oil biodiesel was better (less kg CO2 GJ-1) (b.).

Fig. 3. Allocation approaches. Thamsiriroj and Murphy [48]. 2015 using "LCA" and "biofuel" in title. higher impact on energy intensity than on GWP.

Fig. 2. Cradle to gate energy balance (GJ) and GHG balance (kg CO2) of three biofuels. Data were expressed using in each case two FU: ha of land and GJ of biofuel. In [33] grass biomethane performed better regardless the FU, but there were bigger discrepancies between rapeseed biodiesel and grass biomethane results if FU was set as GJ of fuel (a.). In [34], if results were expressed using ha of land, rapeseed biodiesel performed better (less kg CO2 ha-1), while if FU was switched to GJ of

Fig. 4. Scenarios for LCA comparison of rapeseed biodiesel based on Stephenson et al. [47] and

Fig. 5. Percentage of peer-reviewed LCA studies of biofuels by impact categories assessed. 39 peerreviewed papers were sampled using Science Direct. All papers were published between 2008 and

Fig. 6. Contribution of the three most impacting life cycle stages of corn grain ethanol to the total environmental impact measured in energy intensity (blue) and GWP (red) [42]. Electricity was always the highest contributor to both GWP and energy intensity, but the discrepancies between various life cycle stages were much lower if energy intensity is used as measure. Drying of DDGS has a much

618 


\section{Tables}

620 Table 1. Overview of sixteen selected papers on LCA.

\begin{tabular}{lllcll}
\hline Category & References & Product studied & $\begin{array}{c}\text { Functional } \\
\text { unit }\end{array}$ & System boundaries & Reference system \\
\hline
\end{tabular}

\section{- Biodiesel}

Stephenson et Rapeseed

al. [47] biodiese

\section{1 tonne of} biodiesel

1. Crop production

2.Transport

3. Oil extraction

4. Biodiesel production

5. Distribution

Thamsiriroj Biodiesel from 1. 1 GJ biodiesel 1. Crop production and Murphy palm oil and 2. or 1 ha per 2.Transport

[34] rapeseed year

3. Oil extractio

4. Biodiesel production

5. Distribution

Thamsiriroj and Murphy [33]

Biodiesel from 1. 1 GJ biodiesel Variable rape seed, 2.

tallow and 3.

Used cooking oil and 4. grass

biomethane

Yang et al. Microalgae

[29] biodiesel

\section{- Bioethanol}

\begin{tabular}{|c|c|c|c|}
\hline $\begin{array}{l}\text { Kaufman et } \\
\text { al. [40] }\end{array}$ & $\begin{array}{l}\text { Ethanol from } 1 . \\
\text { corn-grain and } 2 . \\
\text { from corn stover }\end{array}$ & $\begin{array}{l}1 \mathrm{MJ} \text { of } \\
\text { ethanol }\end{array}$ & $\begin{array}{l}\text { 1. Corn production } \\
\text { 2. Transport } \\
\text { 3. Ethanol refining (co-prod } \\
\text { corn-grain ethanol can be fe } \\
\text { cattle; co-product of corn-st } \\
\text { ethanol, electricity is injecte } \\
\text { the grid) }\end{array}$ \\
\hline $\begin{array}{l}\text { Kraatz et al. } \\
{[42]}\end{array}$ & $\begin{array}{l}\text { Corn grain } \\
\text { ethanol }\end{array}$ & $\begin{array}{l}1 \mathrm{~kg} \text { of } \\
\text { ethanol or } 1 \\
\text { MJ of ethanol }\end{array}$ & $\begin{array}{l}\text { 1. Corn grain production } \\
\text { 2. Transport } \\
\text { 3. Ethanol refining } \\
\text { 4. Use of stillage for biogas } \\
\text { production or for animal fed } \\
\text { production }\end{array}$ \\
\hline $\begin{array}{l}\text { Luo et al. } \\
{[30]}\end{array}$ & $\begin{array}{l}\text { Corn stover } \\
\text { ethanol }\end{array}$ & $\begin{array}{l}1 \mathrm{~km} \text { driven in } \\
\text { a midsize car }\end{array}$ & $\begin{array}{l}\text { 1. Agricultural production } \\
\text { 2. Transport } \\
\text { 3. Pretreatment } \\
\text { 4. Fermentation } \\
\text { 5. Distillation } \\
\text { 6. Refining } \\
\text { 7. Blending } \\
\text { 8. Car driving }\end{array}$ \\
\hline
\end{tabular}

\section{- Biomethane}

Korres et al. Grass biomethan [39]

Smyth et al. Grass biomethane [55]

Wang et al. Microalgal biomethane

$1 \mathrm{~m}^{3}$ of

per year, and 13 . Upgrading and compressing of

MJ energy biomethane

replaced 4. Use in a bi-fuel car

5. Digestate use

1 ha per year 1. Crop production

2. Biogas production

3. Upgrading and compressing of biomethane

4. Digestate use

$[28]$

biomethan
1. Algae cultivation (incl. production of photobioreactor)

2. Biogas production

3. Upgrading of biogas

$\begin{array}{ll}\text { Fallow set-aside } & \text { 1. Economic } \\ \text { (alternative land use) } & \text { 2. Substitution }\end{array}$

GWP and primary energy requirement based on EDIP 2003*

Diesel reference system No allocation (all burden to biodiesel)

GHG and energy balance

GHG and energy

Fossil fuel reference 1. No allocation balance

2. Energy

system

3. Substitution
Alternative feedstocks No allocation
Water footprint and nutrients balance
Gasoline reference system

Gasoline reference

system

Gasoline reference system 


\begin{tabular}{|c|c|c|c|c|c|c|}
\hline $\begin{array}{l}\text { Alvarado- } \\
\text { Morales et al. } \\
{[26]}\end{array}$ & $\begin{array}{l}\text { Biogas from } \\
\text { brown seaweed } \\
\text { (and bioethanol }+ \\
\text { biogas) }\end{array}$ & $\begin{array}{l}1 \text { tonne of dry } \\
\text { seaweed }\end{array}$ & $\begin{array}{l}1^{\text {st }} \text { scenario: } \\
\text { 1. Seaweed production } \\
\text { 2. Mechanical pretreatment } \\
\text { 3. Biogas production } \\
\text { 4. Energy production } \\
\text { 2nd scenario: } \\
\text { 3. Bioethanol production } \\
\text { 4. Blending } \\
\text { 5. Car driving } \\
\text { 6. Use of stillage for biogas } \\
\text { production }\end{array}$ & $\begin{array}{l}\text { Coal-based electricity } \\
\text { for biogas, and fossil } \\
\text { gasoline for bioethanol }\end{array}$ & $\begin{array}{l}\text { System expansion } \\
\text { (avoided fertilizer } \\
\text { and energy } \\
\text { production, and } \\
\text { fuel production }\end{array}$ & $\begin{array}{l}\text { GWP, acidification } \\
\text { and terrestrial } \\
\text { eutrophication based } \\
\text { on EDIP } 2003^{*} \\
\text { method, and energy } \\
\text { consumption }\end{array}$ \\
\hline $\begin{array}{l}\text { Börjesson } \\
\text { and Berglund } \\
{[43], \text { and }} \\
\text { Börjesson } \\
\text { and Berglund } \\
{[44]}\end{array}$ & $\begin{array}{l}\text { Biogas systems } \\
\text { (ley crops, straw, } \\
\text { sugar beet, } \\
\text { manure, food } \\
\text { waste, municipal } \\
\text { organic waste) }\end{array}$ & $\begin{array}{l}1 \mathrm{MJ} \text { of } \\
\text { biogas }\end{array}$ & $\begin{array}{l}\text { 1. Handling of raw materials (incl. } \\
\text { crop cultivation) } \\
\text { 2. Biogas production (farm-scale } \\
\text { and large-scale biogas plants) } \\
\text { 3. Biogas and digestate use }\end{array}$ & $\begin{array}{l}\text { Various (fossil fuels and } \\
\text { other bioenergy } \\
\text { systems) }\end{array}$ & $\begin{array}{l}\text { Based on dry } \\
\text { matter content of } \\
\text { the substrates }\end{array}$ & $\begin{array}{l}\text { GWP, acidification, } \\
\text { eutrophication, and } \\
\text { photochemical } \\
\text { oxidant creation } \\
\text { potential }\end{array}$ \\
\hline $\begin{array}{l}\text { Tufvesson et } \\
\text { al. [36] }\end{array}$ & $\begin{array}{l}\text { Biogas from } \\
\text { industrial residues } \\
\text { (distiller's waste, } \\
\text { rapeseed cake, } \\
\text { whey permeate, } \\
\text { fodder milk, and } \\
\text { bakery residues) }\end{array}$ & $\begin{array}{l}1 \mathrm{MJ} \\
\text { upgraded and } \\
\text { compressed } \\
\text { biogas }\end{array}$ & $\begin{array}{l}\text { 1. Transport of feedstocks } \\
\text { 2. Biogas production including } \\
\text { upgrading and compression } \\
\text { 3. Digestate use (no allocation and } \\
\text { system expansion) } \\
\text { 4. Replacement of mineral } \\
\text { fertilizer } \\
\text { 5. Animal feed production } \\
\text { (system expansion) }\end{array}$ & $\begin{array}{l}\text { Petrol and diesel } \\
\text { reference system }\end{array}$ & $\begin{array}{l}\text { 1. No allocation, } \\
\text { 2. System } \\
\text { expansion and } 3 \text {. } \\
\text { allocation rules } \\
\text { based on the } \\
\text { sustainability } \\
\text { criteria defined } \\
\text { by the EU RED }\end{array}$ & $\begin{array}{l}\text { GHG, energy } \\
\text { balance, } \\
\text { eutrophication and } \\
\text { acidification } \\
\text { potential }\end{array}$ \\
\hline
\end{tabular}

* EDIP 2003: Impact assessment method developed by the Institute for Product Development at the Technical University of Denmark [54]

** CML 2001: Impact assessment method developed by the Institute of Environmental Sciences at Leiden University in Netherlands [54].

*** ReCiPe : Impact assessment method developed by various actors: PRé Consultants, CML Leiden University, Radboud University Nijmegen and RIVM

Bilthoven, [51]. 
Table 2. Allocation methodologies according to different sources.

\begin{tabular}{|c|c|}
\hline Institution & Recommended Approach \\
\hline $\begin{array}{l}\text { - Norm ISO } 14044 \text { (International Standard } \\
\text { Organization) }\end{array}$ & $\begin{array}{l}\text { whenever possible avoid allocation and instead use subdivision or system } \\
\text { expansion [15] }\end{array}$ \\
\hline - RED and BioGrace tool & allocation based on energy content (lower heating value) [2] \\
\hline $\begin{array}{l}\text { - BIOMITRE (BIOmass-based Climate Change } \\
\text { MITigation through Renewable Energy) }\end{array}$ & $\begin{array}{l}\text { allocation by economic value (although not ideal since market prices often } \\
\text { fluctuate) [23] }\end{array}$ \\
\hline $\begin{array}{l}\text { - PAS (Publicly Available Specification for assessment } \\
\text { of life cycle GHG of goods and services) }\end{array}$ & $\begin{array}{l}\text { dividing processes into sub-processes or system expansion to include co- } \\
\text { products, by-products, and waste; when neither of these is feasible, then } \\
\text { allocation based on economic value should be applied [22] }\end{array}$ \\
\hline $\begin{array}{l}\text { - UNFCCC through Meth Panel (Methodologies } \\
\text { Panel) }\end{array}$ & all available approaches [66] \\
\hline
\end{tabular}

629 Table 3. Recommendation for LCIA.

\begin{tabular}{|c|c|c|c|}
\hline Impact categories & Indicators & Calculation and unit & Reasons \\
\hline - Climate change & GWP or GHG & $\mathrm{g}$ or $\mathrm{kg} \mathrm{CO}_{2}$-equivalent & $\begin{array}{l}\text { Following legislative requirements to } \\
\text { calculate impact of biofuels on global } \\
\text { warming and potential savings }\end{array}$ \\
\hline - Energy & $\begin{array}{l}\text { Energy balance, net } \\
\text { energy, land use energy } \\
\text { efficiency }\end{array}$ & $\begin{array}{l}\text { Energy balance (output/input } \\
\text { ratio), net energy (gross energy } \\
\text { minus parasitic energy demand) } \\
\text { land use efficiency (energy } \\
\text { production per unit of land); kwh } \\
\text { or MJ (per ha) }\end{array}$ & $\begin{array}{l}\text { Traditional indicator related to } \\
\text { biofuel energy efficiency }\end{array}$ \\
\hline $\begin{array}{l}\text { - Eutrophication } \\
\text { (terrestrial and } \\
\text { aquatic) }\end{array}$ & $\begin{array}{l}\text { Accumulated } \\
\text { exceedance } \\
\text { (terrestrial), ReCiPe } \\
\text { (aquatic) }\end{array}$ & $\begin{array}{l}\text { Terrestrial: modelling following } \\
\text { Seppala et al. [53,62]; kg N eq. } \\
\text { Aquatic: ReCiPe; kg P eq. [51] }\end{array}$ & $\begin{array}{l}\text { Terrestrial strongly correlated with } \\
\text { agriculture and combustion ( } \mathrm{N} \\
\text { compounds); aquatic with } \\
\text { waterborne emissions ( } \mathrm{N} \text { and } \mathrm{P} \\
\text { compounds) }\end{array}$ \\
\hline - Acidification & $\begin{array}{l}\text { Accumulated } \\
\text { exceedance }\end{array}$ & $\begin{array}{l}\text { Modelling following Seppala et } \\
\text { al. }[53,62] \text {; moles of hydrogen } \\
\text { ion }(\mathrm{H}+) \text { eq. }\end{array}$ & $\begin{array}{l}\text { Strongly correlated with transport } \\
\text { and agriculture ( } \mathrm{N} \text { and } \mathrm{S} \text { compounds) }\end{array}$ \\
\hline - Land use & $\begin{array}{l}\text { SOM or surface area of } \\
\text { transformed and } \\
\text { occupied land }\end{array}$ & $\begin{array}{l}\text { mg SOM per year(deficit of SOM) } \\
{[63,64] \text { and } \mathrm{m}^{2} \text { of transformed }} \\
\text { and occupied land }[51]\end{array}$ & $\begin{array}{l}\text { Especially relevant for land-based } \\
\text { biofuels }\end{array}$ \\
\hline
\end{tabular}


Excluded papers

Repetitive (12)

Different scope and aim (11)

LCA-type studies of biofuels (54)

Reviews (10)

Methodological papers (4)

Cost analysis (1)

16 papers retained 
GHG [kg CO2]

4500

4000

3500

3000

2500

2000

1500

1000

500

0

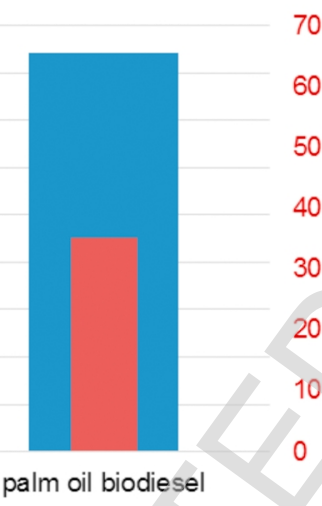

rapeseed biodiesel

60 50

40

20

10

0

- $\mathrm{kg} \mathrm{CO} 2$ / ha of land

\section{Energy balance [GJ]}

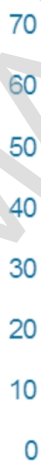

70

60

50

40

30

20

10

0

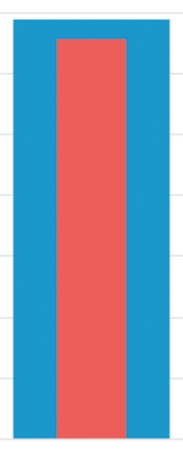

grass biomethane
0.6

0.5

0.4

0.3

0.2

0.1

0 

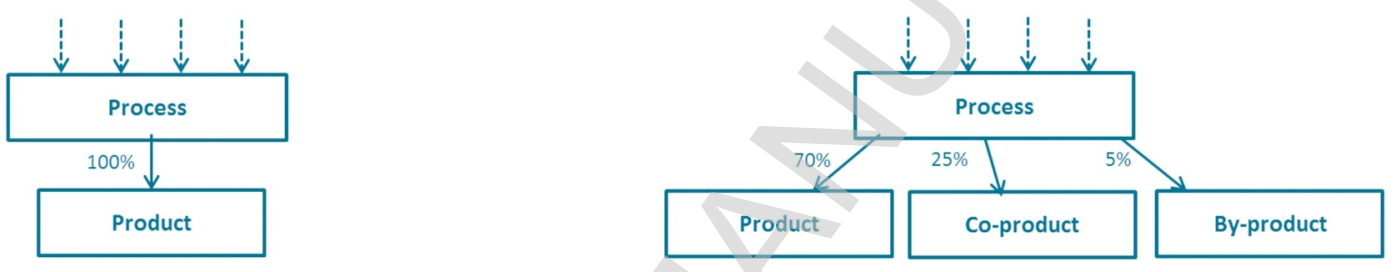

System expansion/ substitution
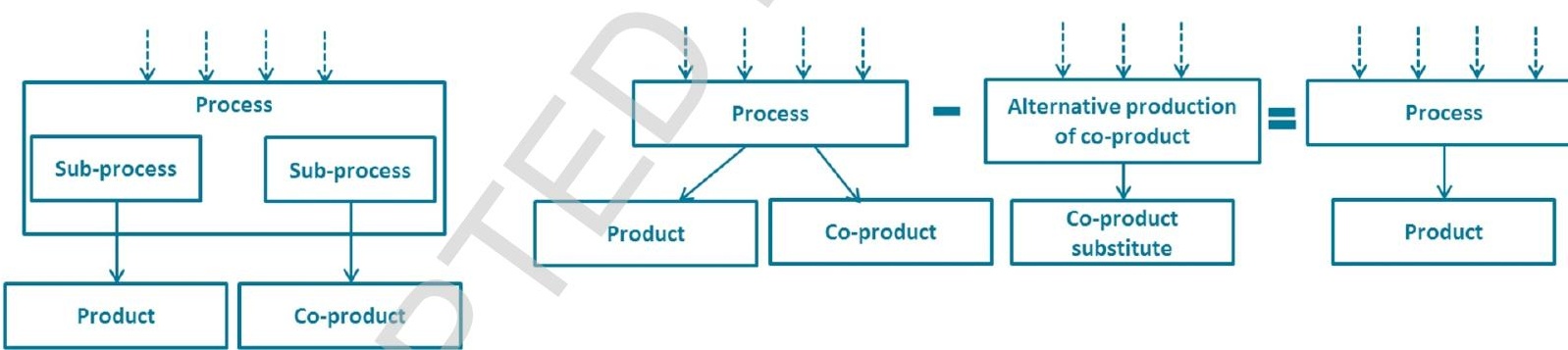


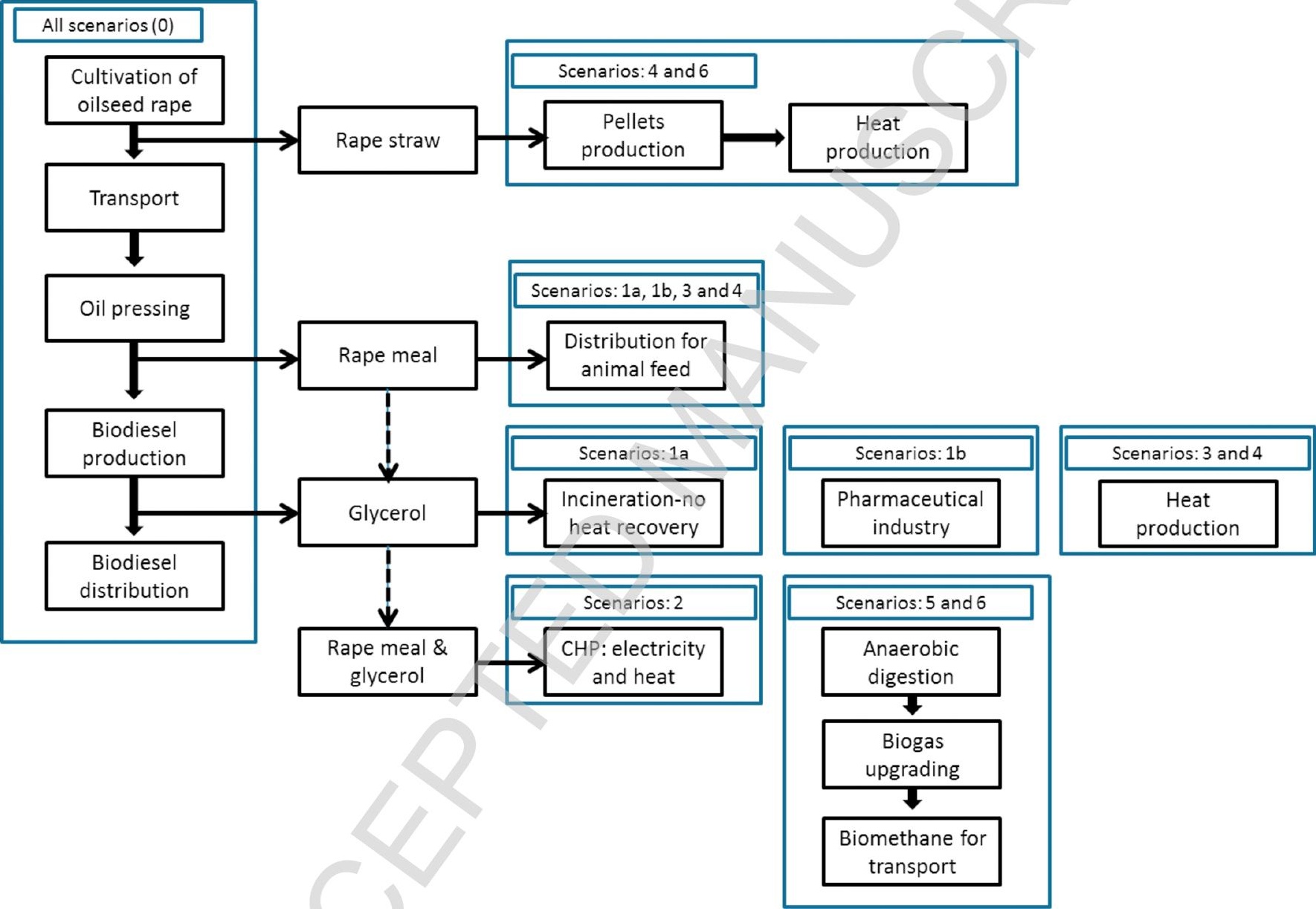




\section{Impact categories}

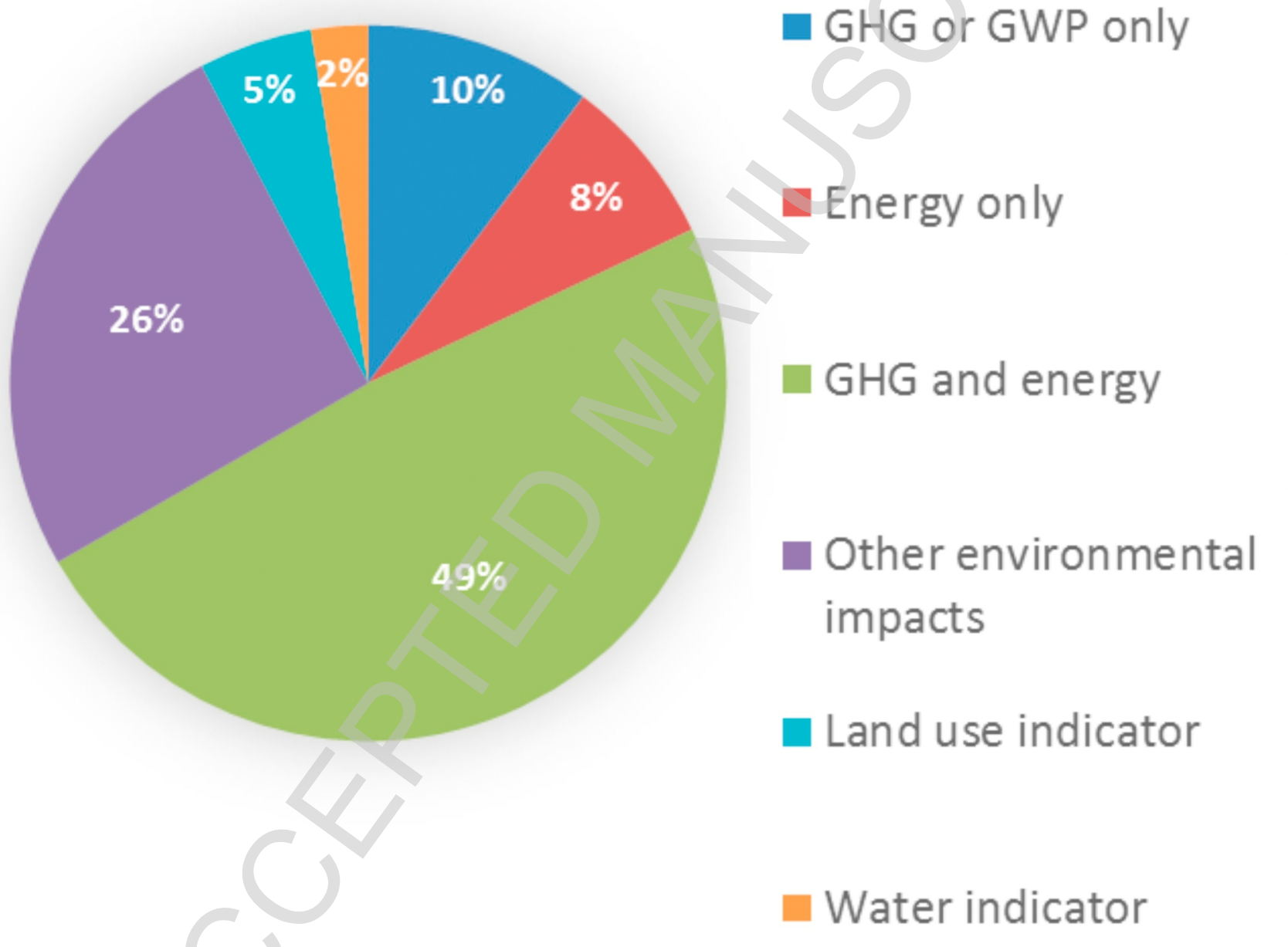




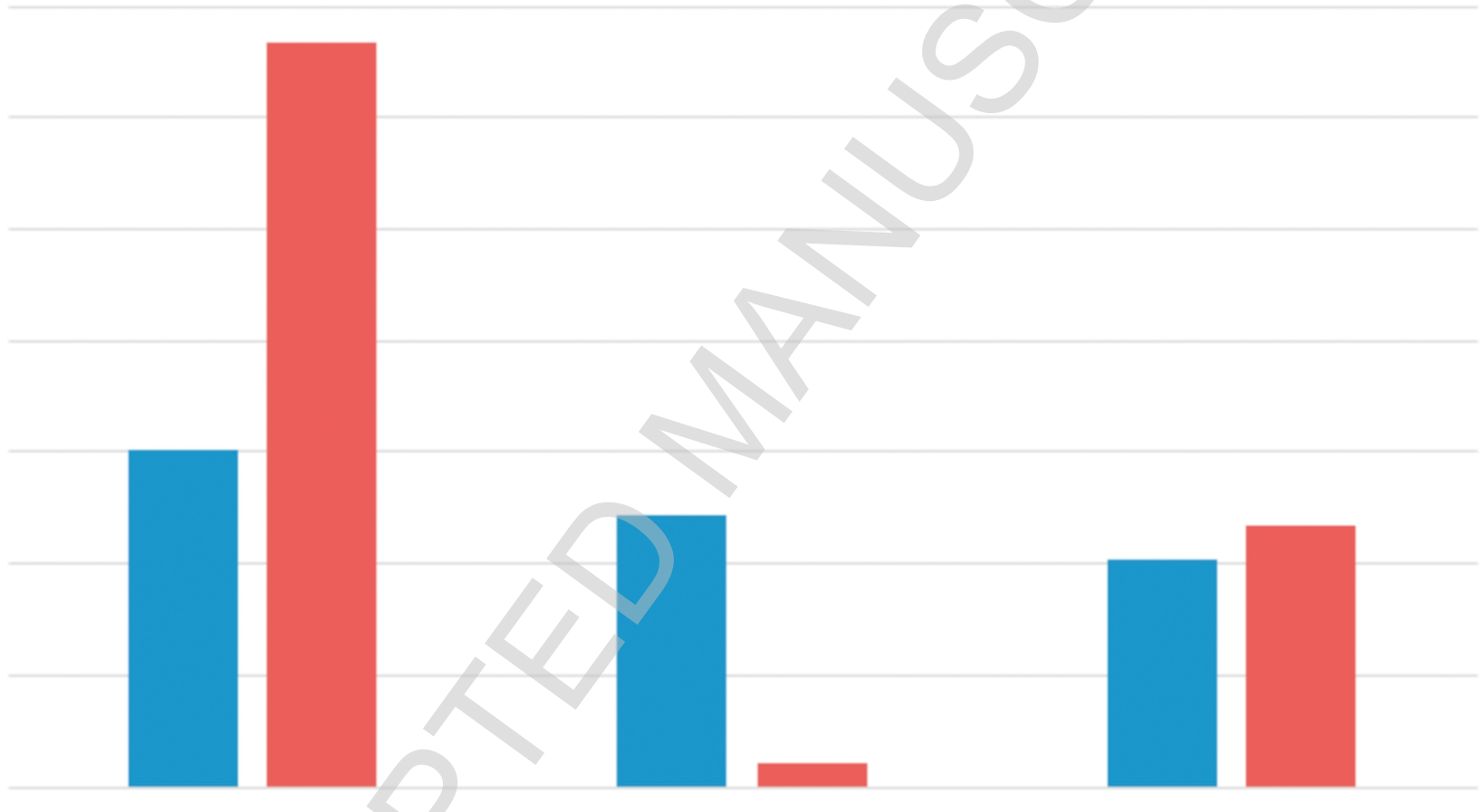

Electricity consumption Drying of DDGS

Corn farming 
1 ha of land

1 tonne of feedstock
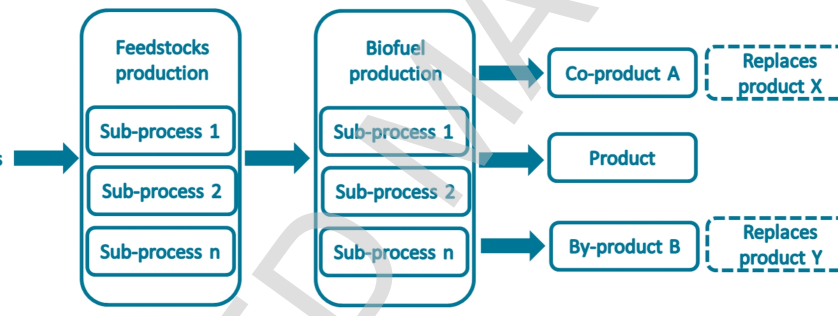

Inputs

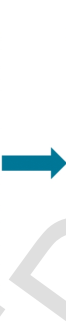

Product

By-product B
$1 \mathrm{MJ}$ of biofuel

1 km driven 